\title{
Infection and inflammation imaging standardization: the EANM guidelines
}

\author{
A. Signore ${ }^{1,3,4}$ (E. Lazzeri ${ }^{2,4} \cdot$ A. W. J. M. Glaudemans $s^{3,4}$
}

Received: 20 June 2018 / Accepted: 23 June 2018 / Published online: 3 July 2018

(c) Italian Association of Nuclear Medicine and Molecular Imaging 2018

Keywords Guidelines $\cdot$ Inflammation $\cdot$ Infection $\cdot$ Standardization

Inflammatory and infectious diseases may have serious consequences for the patient, if not diagnosed in time. In the past decades, nuclear medicine modalities have allowed us to study in depth the pathophysiology of these processes, and today it plays a leading role in the diagnosis, characterization and follow-up of infectious conditions.

Different nuclear medicine techniques and radiopharmaceuticals are currently available for imaging inflammation and infection (including gallium-citrate, radiolabelled white blood cells, anti-granulocyte antibodies and FDG) and it is, therefore, essential for nuclear medicine physicians to have a complete vision of pros and cons of each method and to know how to correctly position nuclear medicine examinations in the diagnostic workup of patients [1-4].

Despite the relevance of nuclear medicine in the field of diagnosis of infectious processes, we observe important differences in diagnostic accuracy of nuclear medicine techniques, between different centres and between different nations. Differences concern the choice of diagnostic procedures to be performed, how these are performed and how results are interpreted. Because of different methodology and different interpretation criteria, conflicting data with

A. Signore

alberto.signore@uniroma1.it

1 Nuclear Medicine Unit, Department of Medical-Surgical Sciences and of Translational Medicine, Faculty of Medicine and Psychology, "Sapienza" University of Rome, Rome, Italy

2 Regional Center of Nuclear Medicine, Pisa University Hospital, Pisa, Italy

3 Department of Nuclear Medicine and Molecular Imaging, University Medical Center Groningen, University of Groningen, Groningen, The Netherlands

4 Inflammation/Infection Committee of the European Association of Nuclear Medicine (EANM), Vienna, Austria wide variability of diagnostic accuracy have been published in the past decades. This variability has not favoured, over the years, the diffusion among the clinicians of the most common methods of nuclear medicine for the diagnosis of infections, such as, for example, the use of radiolabelled autologous leukocytes, or the use of monoclonal anti-granulocyte antibodies or the use of fluordeoxyglucose. This is even more evident, if we look at the results published in recent meta-analyses [5-8]. As a consequence, clinicians have turned mainly to radiological diagnostic investigations (CT, NMR and ultrasound) although not always optimal in the assessment of the extent and activity of the infectious disease, nor useful in the follow-up of therapies unlike nuclear medical methods.

Therefore, since its creation, in 2012, the EANM Committee on Inflammation and Infection has worked on three main goals: (1) the standardization of nuclear medicine techniques for the diagnosis of infection and/or inflammation and their interpretation criteria, (2) the divulgation of these techniques amongst nuclear medicine physicians and (3) the preparation and divulgation of joint diagnostic guidelines with clinicians.

To reach the first goal, several procedural guidelines have been published about how to label autologous white blood cells (WBC) with ${ }^{99 \mathrm{~m}} \mathrm{Tc}-\mathrm{HMPAO}$ [9] or with ${ }^{111} \mathrm{In}$ oxine [10] and about the quality controls that should be performed for the initial validation of the procedure by each centre and on a routine base. Similarly, a guideline on the use of $\left[{ }^{18} \mathrm{~F}\right] \mathrm{FDG}$ in inflammation/infection has been published in 2013 in collaboration with SNMMI [11]. Finally, in the beginning of 2018 the members of the EANM Committee on Inflammation and Infection, in some cases together with other committees and societies, published other important procedural guidelines on multimodality imaging for infective endocarditis [12], for large vessel vasculitis and polymyalgia rheumatica [13], 
Fig. 1 The network of collaborations established over the last 6 years by the EANM Committee on inflammation/infection and other European societies

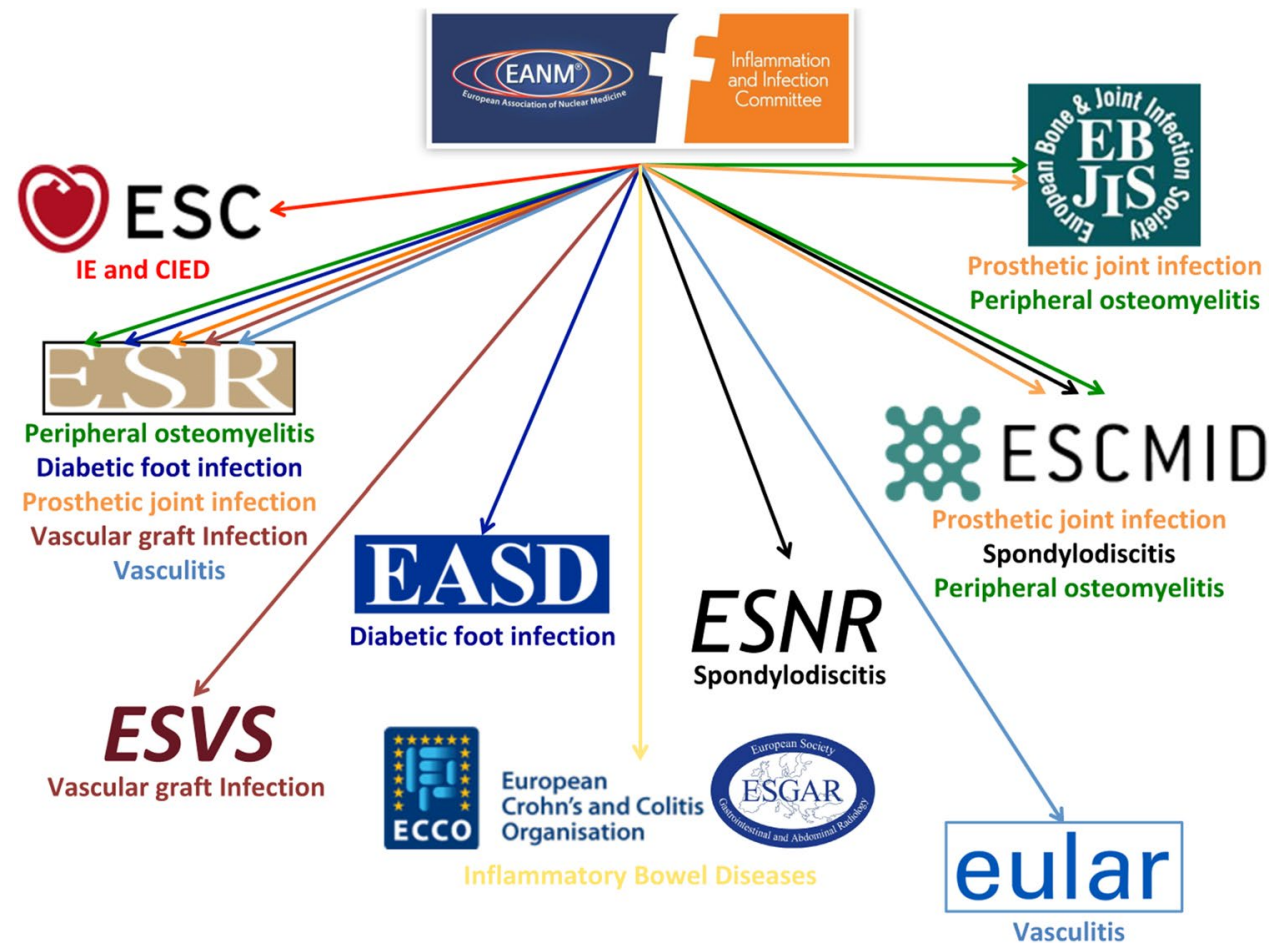

After accomplishing these two goals, we were ready to approach several other European societies to prepare, jointly, diagnostic guidelines. We approached several societies, the European Crohn's and Colitis Organization (ECCO), the European Society of Gastrointestinal Radiology (ESGAR), the European Society of Cardiology (ESC), the European Society of Radiology (ESR), the European Society of Vascular Surgery (ESVS), the European Association for the Study of Diabetes (EASD), the European Society of Clinical Microbiology and Infective Diseases (ESCMID), the European League Against Rheumatism (EULAR), the European Bone and Joint Infection Society (EBJIS) and the European Society of NeuroRadiology (ESNR), as shown in Fig. 1.

With these societies, we organized several symposia and congresses all over Europe and we published in 2015 a monographic issue with a proposal of diagnostic flow charts for the most relevant inflammatory/infective diseases [17-21].

In the last 3 years, the Committee also started several evidence-based guidelines (as shown in Fig. 1) of which two (on infective endocarditis and inflammatory bowel diseases) have been already published [22,23] and others (prosthetic joint infection, peripheral bone infection, spondylodiscitis, vascular graft infection, and infected diabetic foot) will soon be submitted to clinical journals.

With a huge multidisciplinary effort, we reached unanimous consensus to standardize the diagnostic approach in patients with infectious/inflammatory diseases. This consensus has an impact for correct patient management and to harmonize and increase the efficacy of national health care. 


\section{Compliance with ethical standards}

Conflict of interest Alberto Signore, Elena Lazzeri and Andor Glaudemans have no conflict of interest to declare.

\section{References}

1. Signore A, Erba PA (2018) Editorial: Molecular imaging of inflammation/infection: the future of disease management. Curr Pharm Des 24(7):741-742

2. Pacilio M, Lauri C, Prosperi D, Petitti A, Signore A (2018) New SPECT and PET radiopharmaceuticals for imaging inflammatory diseases: a meta-analysis of the last 10 years. Semin Nucl Med 48(3):261-276

3. Signore A, Anzola KL, Auletta S, Varani M, Petitti A, Pacilio M, Galli F, Lauri C (2018) Current status of molecular imaging in inflammatory and autoimmune disorders. Curr Pharm Des 24(7):743-753

4. Sollini M, Lauri C, Boni R, Lazzeri E, Erba PA, Signore A (2018) Current status of molecular imaging in infections. Curr Pharm Des 24(7):754-771

5. Verberne SJ, Sonnega RJ, Temmerman OP, Raijmakers PG (2017) What is the accuracy of nuclear imaging in the assessment of periprosthetic knee infection? A meta-analysis. Clin Orthop Relat Res 475(5): 1395-1410

6. Verberne SJ, Raijmakers PG, Temmerman OP (2016) The accuracy of imaging techniques in the assessment of periprosthetic hip infection: a systematic review and meta-analysis. J Bone Jt Surg Am 98(19):1638-1645

7. Lauri C, Tamminga M, Glaudemans AWJM, Juárez Orozco LE, Erba PA, Jutte PC, Lipsky BA, IJzerman MJ, Signore A, Slart RHJA (2017) Detection of osteomyelitis in the diabetic foot by imaging techniques: a systematic review and meta-analysis comparing MRI, White Blood Cell scintigraphy, and FDG-PET. Diabetes Care 40(8):1111-1120

8. Treglia G, Focacci C, Caldarella C, Mattoli MV, Salsano M, Taralli S, Giordano A (2012) The role of nuclear medicine in the diagnosis of spondylodiscitis. Eur Rev Med Pharmacol Sci 16(Suppl 2):20-25

9. de Vries EF, Roca M, Jamar F, Israel O, Signore A (2010) Guidelines for the labelling of leucocytes with (99m)Tc-HMPAO. Eur J Nucl Med Mol Imaging 37(4):842-848 (Erratum in: Eur J Nucl Med Mol Imaging. 2010 Jun;37(6):1235)

10. Roca M, de Vries EF, Jamar F, Israel O, Signore A (2010) Guidelines for the labelling of leucocytes with (111)In-oxine. Eur J Nucl Med Mol Imaging 37(4):835-841 (Erratum in: Eur J Nucl Med Mol Imaging. 2010 Jun;37(6):1234)

11. Jamar F, Buscombe J, Chiti A, Christian PE, Delbeke D, Donohoe KJ, Israel O, Martin-Comin J, Signore A (2013) EANM/SNMMI guideline for 18F-FDG use in inflammation and infection. J Nucl Med 54(4):647-658

12. Erba PA, Lancellotti P, Vilacosta I, Gaemperli O, Rouzet F, Hacker M, Signore A, Slart RHJA, Habib G (2018) Recommendations on nuclear and multimodality imaging in IE and CIED infections. Eur J Nucl Med Mol Imaging. https://doi.org/10.1007/s00259-018-4025-0 (Epub ahead of print)

13. Slart RH, Glaudemans AW, Chareonthaitawee P, Treglia G, Besson TL, Bley TA, Blockmans D, Boellaard R, Bucerius J, Carril JM, Chen W, Cid MC, Dagupta B, Dorbala S, Gheysens O, Hyafil F, Jain S, Klink T, van der Laken CJ, Lomena F, Massollo M, Prieto-Gonzalez S, Luqmani R, Roivainen A, Salvarini C, Saraste A, Schirmer M, Verberne HJ, Versari A, Voskuyl AW, Walter MA, Camellino D, Brouwer E, Cimmino MA, Reviewer Group (2018)
FDG-PET/CT(A) imaging in large vessel vasculitis and polymyalgia rheumatica: joint procedural recommendation of the EANM, SNMMI, the PET Interest Group (PIG), and endorsed by the ASNC. Eur J Nucl Med Mol Imaging 45:1250-1269

14. Slart RH, Glaudemans AW, Lancelotti P, Hyafil F, Blankstein R, Schwartz R, Jaber WA, Russell R, Gimelli A, Rouzet F, Hacker M, Gheysens O, Plein S, Miller EJ, Dorbala S, Donal E, Document Reading Group (2017) A joint procedural position statement on imaging in cardiac sarcoidosis: from the cardiovascular and inflammation and infection committees of the European Association of Nuclear Medicine (EANM), the European Association of Cardiovascular Imaging (EACVI), and the American Society of Nuclear Cardiology (ASNC). Eur Heart J Cardiovasc Imaging 18(10):1073-1089

15. Slart RH, Glaudemans AW, Lancelotti P, Hyafil F, Blankstein R, Schwartz R, Jaber WA, Russell R, Gimelli A, Rouzet F, Hacker M, Gheysens O, Plein S, Miller EJ, Dorbala S, Donal E, Document Reading Group (2011) A joint procedural position statement on imaging in cardiac sarcoidosis: from the cardiovascular and inflammation and infection committees of the European Association of Nuclear Medicine (EANM), the European Association of Cardiovascular Imaging (EACVI), and the American Society of Nuclear Cardiology (ASNC). J Nucl Cardiol 25(1):298-319

16. Signore A, Jamar F, Israel O, Buscombe J, Martin-Comin J, Lazzeri E (2018) Clinical indications, image acquisition and data interpretation for white blood cells and anti-granulocyte monoclonal antibody scintigraphy: an EANM procedural guideline. Eur J Nucl Med Mol Imaging. https://doi.org/10.1007/s00259-018-4052-x (Epub ahead of print)

17. Jutte P, Lazzeri E, Sconfienza LM, Cassar-Pullicino V, Trampuz A, Petrosillo N, Signore A (2014) Diagnostic flowcharts in osteomyelitis, spondylodiscitis and prosthetic joint infection. Q J Nucl Med Mol Imaging. 58(1):2-19

18. Martin-Comin J, Laghi A, Reinisch W (2014) Common diagnostic flow charts for diagnosis and management of patients with an inflammatory bowel disease. Q J Nucl Med Mol Imaging 58(1):20-32

19. Israel O, Sconfienza LM, Lipsky BA (2014) Diagnosing diabetic foot infection: the role of imaging and a proposed flow chart for assessment. Q J Nucl Med Mol Imaging 58(1):33-45

20. Setacci C, Müller-Hülsbeck S, Jamar FX (2014) Common diagnostic flowcharts in vascular and endovascular surgery. Q J Nucl Med Mol Imaging 58(1):46-54

21. Iung B, Erba PA, Petrosillo N, Lazzeri E (2014) Common diagnostic flowcharts in infective endocarditis. Q J Nucl Med Mol Imaging 58(1):55-65

22. Panes J, Bouhnik Y, Reinisch W, Stoker J, Taylor SA, Baumgart DC, Danese S, Halligan S, Marincek B, Matos C, Peyrin-Biroulet L, Rimola J, Rogler G, van Assche G, Ardizzone S, Ba-Ssalamah A, Bali MA, Bellini D, Biancone L, Castiglione F, Ehehalt R, Grassi R, Kucharzik T, Maccioni F, Maconi G, Magro F, Martín-Comín J, Morana G, Pendsé D, Sebastian S, Signore A, Tolan D, Tielbeek JA, Weishaupt D, Wiarda B, Laghi A (2013) Imaging techniques for assessment of inflammatory bowel disease: joint ECCO and ESGAR evidence-based consensus guidelines. J Crohns Colitis 7(7):556-585

23. Habib G, Lancellotti P, Antunes MJ, Bongiorni MG, Casalta JP, Del Zotti F, Dulgheru R, El Khoury G, Erba PA, Iung B, Miro JM, Mulder BJ, Plonska-Gosciniak E, Price S, Roos-Hesselink J, Snygg-Martin U, Thuny F, Tornos Mas P, Vilacosta I, Zamorano JL, ESC Scientific Document Group (2015) 2015 ESC Guidelines for the management of infective endocarditis: the Task Force for the Management of Infective Endocarditis of the European Society of Cardiology (ESC). Endorsed by: European Association for CardioThoracic Surgery (EACTS), the European Association of Nuclear Medicine (EANM). Eur Heart J 36(44):3075-3128 